\title{
UNDERSTANDING OF SYMBOLIC VIOLENCE IN REALIZING THE CONDUCIVE EDUCATIONAL ECOSYSTEM (STUDY ON MAN KOTA BATU)
}

\author{
Sabilla Amirulloh \\ Sociology teacher at MAN Kota Batu, Head of Anthropology MGMP Planner in East Java Province. \\ sabilamier@pergumapi.or.id
}

\begin{abstract}
Abstrak
Fenomena kekerasan di lingkungan sekolah sampai saat ini masih terjadi. Kekerasan tersebut dapat berwujud kekerasan fisik, kekerasan verbal, kekerasan psikis dan kekerasan simbolik. Berbagai bentuk kekerasan tersebut selama ini dipahami sebagai upaya sekolah untuk mendisiplinkan peserta didiknya. Akan tetapi kekerasan tersebut dapat memberikan dampak lingkungan pendidikan menjadi tidak kondusif. Penelitian ini bertujuan untuk menggali lebih dalam mengenai pemahaman sekolah terhadap kekerasan simbolik dalam mewujudkan ekosistem pendidikan kondusif di Madrasah Aliyah Negeri Kota Batu. Untuk mencapai tujuan tersebut, penelitian ini dilakukan dengan mneggunakan pendekatan penelitian kualitatif. Subjek dari penelitian ini adalah guru dan murid yang berada dalam arena kekerasan simbolik, yakni di lingkungan sekolah. Pengumpulan data menggunakan observasi, wawancara dan dokumentasi. Data yang diperoleh dianalisis dengan menggunakan teknis analisis dari Miles dan Huberman dengan tahapan kondensasi data, penyajian data, dan pengambilan kesimpulan. Uji keabsahan data menggunakan triangulasi data dan triangulasi metode. Penelitian ini dianalisis dengan menggunakan perspektif kekerasan simbolik Pierre Bourdieu. Hasil penelitian ini menunjukkan bahwa tidak ada niatan dari pihak sekolah untuk melakukan kekerasan atas dasar kekuasaan yang mereka miliki. Tindakan tegas yang dilakukan semata-mata sebagai proses pendisiplinan kepada peserta didik. Tindakan tersebut ditujukan supaya peserta didik memiliki 'moral kehormatan' yang berguna bagi mereka dan menciptakan ekosistem pendidikan yang kondusif. Walaupun kadang mendapat reaksi dari peserta didik namun tindakan ini dapat mereka pahami sebagai tindakan yang memang sudah sewajarnya dilakukan oleh pihak sekolah dalam menghadapi penyimpangan yang dilakukan oleh beberapa peserta didik.
\end{abstract}

Kata kunci: ekosistem pendidikan, kekerasan simbolik, sekolah kondusif

\begin{abstract}
The phenomenon of violence in the school environment is still happening. Such violence may be physical violence, verbal violence, psychic violence, and symbolic violence. Various forms of violence have been understood as a school effort to discipline students. However, that violence may potentially impact the educational environment to be non-conducive. This study aims to explore more deeply about the
\end{abstract}


school's understanding of symbolic violence in realizing a conducive educational ecosystem in Madrasah Aliyah Negeri Kota Batu. To achieve that goal, this research is done by using a qualitative research approach. Subjects of this study were teachers and students who were in the arena of symbolic violence, namely in the school environment. Data collection uses observation, interview, and documentation. The data obtained were analyzed using technical analysis from Miles and Huberman with data condensation, data display, and conclusion. Test data validity uses data triangulation and method triangulation. This study was analyzed using the perspective of symbolic violence of Pierre Bourdieu. The results of this study indicate that there is no intention from the school to commit violence on the basis of their power. The assertive action was taken solely as a disciplining process to learners. The action is aimed at students to have a 'moral honor' that is useful to them and create a conducive educational ecosystem. Although sometimes get a reaction from learners but this action they can understand as an action that is naturally done by the school in the face of irregularities committed by some learners.

Keywords: educational ecosystem, symbolic violence, and school conducive

\section{Introduction}

All of the Indonesian people must gain a good education to develop their own skills as this is the right of every citizen that contains in Law No. 20 of 2003 on the national education system. Meanwhile, every parent of student expects their children to achieve the best education in school in form either facility, quality, or service from their teachers, whereas Students honestly hope to experience safe and comfortable atmosphere when studying in school. In the Strategic Plan of Education and Culture Ministry, one of the goals set is to create the conducive educational ecosystem. The educational ecosystem in question is covering the interaction of all school people and people with the school's environment too. Schools that have a comfortable environment or ecosystem can be comprehended as a place in which there is a relationship of interdependence between humans with each other as well as between humans and their environment.
However, in reality, the school is not always the conducive place where the phenomenon of violence in the education environment is still common today. The forms of violence that we can easily find in the school environment include physical, verbal and mental violence. Physical violence is the most easily observed evidence because it causes injuries to the physical victim such as pinching, slapping, hitting, and upwards. Verbal violence is violence carried out through words that hurt the victim's feelings such as cursing, defaming, and throwing other inappropriate words, whereas mental violence is violence that makes victims become powerless to rise up such of threats, condescension and so on.

Beside to the types of violence above, actually, there have still been forms of violence that rarely pay attention from the public as Pierre Bourdieu (Bourdieu, 1995) calls symbolic violence. Symbolic violence is subtle violence that is not realized by the 
victim. The concept of this violence is driven to explain the efforts of the dominant class in perpetuating its habitus to the dominated class.

The practice of symbolic violence can be delivered in two distinct ways (Haryatmoko, 2003). First, euphemism is a mechanism of symbolic violence by conditioning symbolic violence to be invisible, working subtly, difficult to recognize, and chosen unconsciously. The form of euphemism often occurs in the form of trust, obligation, loyalty, courtesy, giving, debt, reward, and mercy. Second, censorship mechanism is by shaping a symbolic violence seen as a form of preservation in all forms of values that are considered "moral honor", such as politeness, purity, generosity, etc. that are usually contradicted with what is called "low morality" includes violence, crime, impropriety, immorality, greed, and so on. Based on the background described above, the problems that will be explored in this study are how do schools understand symbolic violence in realizing a conducive educational ecosystem in Madrasah Aliyah Negeri Kota Batu (MAN Kota Batu)?

\section{Research methods}

This study uses a qualitative approach that prioritizes observation of symptoms and/or facts that exist in the field and then tries to describe them in the form of words and languages (Moleong, 2010: 5-13). The description of those facts will generate a concept of school understanding of symbolic violence that occurs in the educational environment in the tremendous efforts to realize the conducive educational ecosystem. Qualitative research methods are also well known as naturalistic research. This is due to the research is carried out in natural settings where natural subjects that develop as those are not manipulated by researchers, and the presence of researchers will not exactly affect the dynamics of the subjects observed (Sugiyono, 2013: 8).

This research was carried out at MAN Kota Batu in which in this school there are cases of symbolic violence caused by high demands on students as stated in the school's vision and mission. Based on the serious demands to form perfect children's attitudes and behaviors, it results in educators carrying out symbolic violence in order to achieve the target in accordance with the prescribed vision and mission. This research was conducted from July 2017 to April 2018.

To analyze the results of the study, researcher employes the data analysis techniques that can be run through two stages, namely: (1) analysis of data in the field and (2) analyzing after the collected data. The next step is to analyze the data using several steps as stated by Miles, Huberman, and Saldana (2014), including condensation data, data display, and finally conducting the process of conclusion drawing and verification. 


\section{Data Presentation and Discussion}

Understanding of Schools on the Symbolic Violence Mechanism

The mechanism for implementing symbolic violence can be done in two ways (Haryatmoko, 2003). Firstly, a mechanism called euphemism is an approach for carrying out symbolic violence by making symbolic violence to be invisible, working smoothly, difficult to recognize, and can be chosen "unconsciously" by the victim. The form of euphemism that occurs in the school environment can be in the term of trust, obligation, loyalty, courtesy, giving, debt, merit, or mercy. Secondly, the mechanism of symbolic violence can be carried out through what is called censorship, which makes symbolic violence visible as preservation in all forms of values considered as "moral honor", for instance, politeness, chastity, generosity, etc. It contrasted with what is called "low morality" such as violence, crime, impropriety, immorality, greed, and so on.

\section{Understanding of Schools on Euphemism and Censorship}

Associated with the mechanism of euphemism in symbolic violence, teachers at MAN Kota Batu did not realize that what they run in the learning process is a form of the symbolic violence practice. According to them, what they did were a form of learning to instill discipline and kindness. The teachers explained that in learning activities, giving orders, prohibitions, and rewards as well as applying courtesy are common things and indeed aims to create conducive situations in teaching and learning activities.

The occurrence of violence in schools could be felt because of the unequal relations' pattern, in which the position of the teacher is as the dominant party and the student as the discriminated side. But this is not always understood as a form of violence even by the students themselves, even some students grasp this as naturally as it happens. In common perception, when there are recalcitrant students or violating the rules it is only natural for the teacher to take certain actions to punish the students, such as angering or even yelling and maybe taking physical action. In the educational environment, the school makes orders and/or prohibitions deemed reasonable by students. They consider precisely it is not the form of violence, but rather is fairness as an attempt to discipline students and create a conducive environment.

Moreover, the censorship mechanism that makes symbolic violence appear as a part of preservation in all forms of values that are considered as "moral honor", such as politeness, chastity, generosity, etc. which are usually contradicted with "low morality" like violence, crime, impropriety, immorality, gluttony, and so on. By using "moral honor" and "low morale" pretext, a teacher often commits violence on the pretext of enforcing discipline. Students are involuntarily forced to accept well-perceived values without being able to think critically. 
From the vision and mission of MAN Kota Batu, all of these refer to what is called as "moral honor", whilst the implementation through what Bourdieu calls censorship is understood by schools as an effort to create goodness, discipline, and efforts to realize a conducive educational ecosystem. Furthermore, extracurricular activities are not thought as the preservation of upperclass habitus as explained in the concept of Bourdieu's symbolic violence, but it is understood by the school as an attempt to realize one of the school's missions, namely "Organizing training in life skills based on the morality of Karimah." As a logical consequence, all students are required to take a part in the extracurricular activities.

In order to uphold moral honor intended to realize the conducive education ecosystem, sometimes teachers unconsciously conducted verbal violence when finding the violations done by students. In other words, they recognized that there is no intention to demean students but to discipline them.

From the results of interviews, it can be deduced the censorship mechanism that contradicts to "moral honor" and "low morale" carried out by MAN Kota Batu has no intention to maintain the upper-class habitus. This is strongly wished to create a discipline that refers to "moral honor". If all students have such moral honor, it is hoped that a conducive educational ecosystem can be realized, especially in MAN Kota Batu.
Understanding of Schools on Doxa and

\section{Habitus}

Doxa is basically the view of the ruler which is deemed as the perception of the whole society. In the educational area, the views of the teacher can be considered as doxa. Whatever is said and done by the teacher it is wondered as the truth by the students. This is because the teacher is deliberated to have symbolic capital so that the teacher is in the dominant class. For example, a teacher that shows the authoritarian is in the classroom, but none of his students dares to fight because his students think it is a truth. As any examples that the teacher instructs, the student would obey and implement it. In the school environment, the teacher gives a wide range of view that does not mean the position of a ruler, but the position as a role model.

Moreover, habitus is social values internalized by humans in a process that runs in a long time. These values and habits settle into a mindset and way of behaving in society. According to the concept of symbolic violence, a good habitus is owned by the upper class due to this kind of habitus can be categorized as "moral honor". Upscale habitus in the educational environment is, for example, neat, diligent, reading, writing, and discussing, but in reality, not all students have habitus like these.

To generate the conducive education ecosystem, teachers sometimes do make the doxa even though they have no intention to force it as the dominant party. The teachers 
consider deliberately that good habits should be carried out by students. When all students do run these good deeds, a conducive school ecosystem is believed to be realized.

\section{Understanding of Schools on Symbolic Violence to Achieve a Conducive Educational Ecosystem}

Based on this study, the researcher found that there is a different cultural perspective between Bourdieu and perspective that was found in the field. In the world of education, production and reproduction occur or re-create symbolic violence to benefit certain classes. In the field, it was found that symbolic violence had a function. Symbolic violence is functional, namely to create discipline as explained by Mr. Sudirman:

"The school through the teachers using symbolic capital pursues to gain the confidence of the students in order to discipline them. Students who commit violations should indeed be given a warning so as not to repeat the mistake again, but should they be given in a way that is good and not offensive."

A safe and orderly school environment is that it can provide a conducive school environment. Therefore, a strong and wise leadership role is very necessary and the school should be able to provide a sense of security for all their citizens. In order to reach these conditions, the construction must be strong according to applicable standards; beautiful shape, air circulation and light safe for health, size of furniture and placement safe for health, and far from immoral places and insecure places.

Likewise, discipline in the school environment is very important, in which an orderly school is a place that applies rules indiscriminately and is able to create school discipline properly. The conducive educational environment is that it can arouse learning enthusiasm and become a motivating factor, which can provide a special attraction for the learning process. To create the conducive environment, it must be supported by a variety of adequate and good learning facilities and a harmonious relationship between educators and students and others.

The conducive education ecosystem is an environment that all citizens interact in a comfortable atmosphere. There are no violations committed by school residents as well as there is no destruction of school people towards the environment and the interaction process runs in a pleasant condition. Students do need to learn for discipline, especially self-discipline, but to teach these disciplines is not by giving physical and condescending punishment because it has proven to be ineffective in enforcing discipline. It is best for the teacher to tell and explain to students what mistakes they have done not by giving physical or condescending punishment. Teachers need 
to be given the knowledge, understanding, and skills to drive disciplinary methods that are not in the form of physical punishment, or punishments that demean children.

\section{Conclusion}

The phenomenon of violence still occurs in the educational environment. The types of violence that occur include physical, verbal, and psychological violence. In addition, there is one more form of violence put forward by Pierre Bourdieu in the school environment, called symbolic violence. The violence is executed smoothly so that it is not seen even by the victim. Understanding of symbolic violence that happens in the school environment is still multiple interpretations. The first understanding of symbolic violence is interpreted as a form of violence that should not occur. The second understanding is as a way to discipline students for building a conducive education. Symbolic violence exists and occurs in the school environment, but it is not recognized as a term of violence. It is as a way to regulate students. In the school environment, symbolic violence is carried out by the teacher as the dominant party to the students as the discriminated party. Symbolic violence conducted by teachers is carried out using the mechanism of euphemism and censorship.

\section{Suggestion}

\section{For School Parties}

Doing discipline must be run by the school as an effort to realize a conducive education ecosystem. Shows 'moral honor' must be done by the school as an attempt to facilitate good provisions for all students. But, disciplinary effort should be banned to eventually lead acts of violence which consequently will harm all parties. However, doing the perform discipline in a good and wise way is the best solution.

\section{For students}

It should be understood that it has become a school task to educate and direct students for doing good behavior or what Bourdieu calls "moral honor." Firm actions from the school are merely disciplinary efforts to create a conducive educational ecosystem. Do not let the disciplinary effort of this school to be understood as a form of violence on the basis of power or hatred. When the educational environment is conducive, the teaching and learning process in schools will be more safe and comfortable for all citizens. 


\section{BIBLIOGRAPHY}

Bachtiar, Wardi. 2006. Sosiologi Klasik dari Comte hingga Parsons. Bandung: Remaja Rosdakarya.

Bourdieu, Pierre. 1995. Outline of Theory of Practice. Cambridge: Cambridge University Press.

Berry, David. 1983. Pokok-Pokok Pikiran dalam Sosiologi disuntingoleh Paulus Wirutomo. Jakarta: Rajawali.

Burhanudin, Tamyis. 2001. AhklakPesantren, Pandangan KH. HasyimAsy'ari. Yogyakarta: Ittaka Press.

Creswell, John W. 2009. RESEARCH DESIGN: Qualitative, Quantitative, and Mixed Methods Approaches. United Stated of America: SAGE Publications.

Denzin, Norman K., and Lincoln, Yvonna S. 2009. Handbook of qualitative research (terjemahan). Yogyakara: PustakaPelajar.

Freire, Paulo. 2001. Pendidikan yang Membebaskan, Pendidikan yang Memanusiakan, dalam Menggugat Pendidikan. Yogyakarta: PustakaPelajar.

Martono, Nanang, 2012. Kekerasan Simbolik di Sekolah Sebuah Ide Sosiologi Pendidikan Pierre Bourdieu. Jakarta: Rajawali Pers.

Miles, M.B, Huberman, A.M, dan Saldana, J. 2014. Qualitative Data Analysis, A Methods Soucebook, Edition 3. USA: Sage Publications. Terjemahan Tjetjep Rohindi, UI-Press.
Ritzer, George. 2016. Sosiologi Ilmu Pengetahuan Berparadigma Ganda Penerjemah Alimandan. Jakarta: PT RajaGrafindoPersada.

Ritzer, George dan Douglas J. Goodman. 2005. Teori Sosiologi Modern diterjemahkan oleh Alimandan. Jakarta: Kencana.

Rencana Strategis Kementerian Pendidikan dan Kebudayaan Tahun 2015-2019.

Brigitte C. Scott. 2012. Caring Teachers and Symbolic Violence: Engaging the Productive Struggle in Practice and Research. Educational Studies. Vol. 48: 530-549.

Douglas McKnight and Prentice Chandler. 2012. The Complicated Conversation of Class and Race in Social and Curricular Analysis: An Examination of Pierre Bourdieu's Interpretative Framework in Relation to Race. Educational Philosopy and Theory. Vol. 44. No. S1: 74-97.

Eric Toshalis. 2010. From Disciplined to Disciplinarian: The Reproduction of Symbolic Violence in Pre-service Teacher Education. J. Curriculum Studies. Vol. 42. No.2: 183-213.

Syahril. 2014. Arena Produksi Kultural dan Kekerasan Simbolik. Jurnal Ilmiah Peuradeun. Vol. 2, No. 1.

Ulfah. 2014. Eufemisasi Sebagai Mekanisme Kekerasan Simbolik dalam Pembelajaran di Sekolah. Jurnal Kreatif Untad. Vol. 16, No. 3, hlm 80-86. 
http: / / zayyan-zulfahmi.blogspot. http://www.uin-malang.ac.id/r/101001/ co.id/2011/04/etika-guru-dan-murid- triangulasi-dalam-penelitian kualitatif. dalam-pendidikan.html html 